\title{
Variation in the Incidence of Renal Adenocarcinoma Among Rana pipiens Held Under Tumor-promoting Conditions
}

\author{
ROBERT G. McKINNELL ${ }^{3}$, EVILLE GORHAM ${ }^{2}$, AND DEAN G. BINGER ${ }^{1}$ \\ University of Minnesota, Saint Paul 55108 and Minneapolis 55455
}

\begin{abstract}
In 1975-1976, significant differences were observed in the frequencies of renal tumors in wild-caught frogs from different sites when they were held in the laboratory under tumor-promoting conditions. In 1979-1980, tumors could not be induced in frogs from a site where spontaneous tumors were no longer detectable. It is suggested that because spontaneous tumors have decreased in natural populations, it is less likely that the etiologic agent - the Lucké-tumor herpesvirus - will be present to promote tumor development under the stress of laboratory conditions.
\end{abstract}

\section{INTRODUCTION}

Leopard frogs Rana pipiens from the N-central and northeastern United States, may become afflicted with a renal adenocarcinoma (Lucké, 1934; McKinnell, 1973; McKinnell, in press a, b). The etiological agent is the Lucké tumor herpesvirus (Naegele et al., 1974). Tumor prevalence in natural populations of untreated frogs has varied considerably over time. In the late 1960 s and early 1970 s it averaged $4.2 \%$ in 1870 frogs collected from four Minnesota counties but decreased strikingly in 1977-1980 (McKinnell, in press a, b; McKinnell et al., 1979, 1980), with no tumors observed in 2342 frogs collected from the same counties.

Leopard frogs housed in the laboratory for several months, under tumorpromoting conditions (Rafferty 1963a, b) such as those used in this study, develop renal tumors at a frequency several times greater than the spontaneous frequency in natural populations. Whether laboratory conditions induce stress by confinement, prolonged exposure to temperatures relatively high for frogs in nature, inappropriate diet, or other factors that promote the appearance of tumors, is not known. Rafferty and Rafferty (1961) maintained uninoculated frogs under tumor-promoting laboratory conditions for as long as 41 weeks. Tumor incidence after the 30 th week varied in different groups between $20 \%$ and $50 \%$, with a mean incidence of $26 \%$. Later, Rafferty (1963a) maintained wild-caught frogs for 8 months either individually or in crowded tanks of 11 or 12 frogs. The final tumor incidence in the 216 frogs of the study was $23.8 \%$ for isolated frogs and $23.5 \%$ for crowded frogs. According to DiBerardino and King (1965), frogs held under tumor-promoting conditions for a substantially longer time (34 months) developed a higher tumor incidence when more crowded (40\%) than when less crowded $(13 \%)$.

Body length and laboratory temperature were shown by Rafferty (1962) to be important factors in tumor promotion. Body length was positively correlated with tumor incidence in frogs held at $23 \mathrm{C}$. Male frogs as small as 55-59 mm body length developed tumors $(11 \%)$, but this rate was substantially less than that $(47 \%)$ obtained in male frogs 75-84 mm long. Frogs failed to develop tumors when held at $13.5 \mathrm{C}$, in corrtrast to a tumor incidence in excess of $30 \%$ when held at $26.5 \mathrm{C}$.

Rafferty (1963b) reported that tumor incidence was unaltered by injection of extracts from frog-kidney tumors. Similar results were reported by Roberts (1963), who

\footnotetext{
${ }^{1}$ Department of Genetics and Cell Biology.

${ }^{2}$ Department of Ecology and Behavioral Biology (E.G.).

${ }^{3}$ Royal Society Guest Research Fellow, Nuffield Department of Pathology

John Radcliffe Hospital

University of Oxford

Oxford OX3 9DU, U.K., through August 1982
} 
maintained frogs in the laboratory for 4 months with or without injection of a tumor extract and under crowded conditions or individually. These factors did not affect the overall tumor frequency of $17 \%$.

This study was undertaken for two main reasons. First, we wanted to determine whether there are geographic differences among frog populations in their susceptibility to tumor-promoting laboratory conditions. Second, we wished to ascertain whether tumors could be induced under such conditions in frog populations no longer exhibiting tumors in nature.

\section{Materials And Methods}

Two experiments are reported here.

Experiment 1. - This experiment was started 3 October 1975 and continued through 16 June 1976. Frogs were collected from three sites in Minnesota where tumors had been detected in the past (McKinnell, 1969; McKinnell et al., 1979) and one site in North Dakota where tumors were not previously known (McKinnell and Duplantier, 1970). Fifty frogs, 25 male and 25 female, were collected in grassy fields near the Sand Hill River, 5 miles east of Fertile, Polk County, Minn., on 3 October 1975. On the same day 50 frogs, 25 male and 25 female, were obtained near Chippewa Lake, 11 miles NW of Alexandria, Douglas Co. Fifty frogs, 25 male and 25 female, were collected near Diamond Lake, 5 miles NW of Atwater, Kandiyohi Co., on 16 and 19 October 1975. Twenty-three frogs, eight male and 15 female, were collected on the margins of several small lakes, Northern Prairie Wildlife Research Station, Woodworth, Stutsman County, North Dakota, on 18 October 1975.

The frogs were housed in individual glass jars containing approximately $250 \mathrm{ml}$ of dechlorinated tap water. The frogs were force-fed liver dipped in cod liver oil and a multivitamin-mineral supplement (Clovite, Fort Dodge Labs, Fort Dodge, Iowa $50501)$ three times weekly. Laboratory temperature was $25 \mathrm{C}( \pm 2)$. One hundredfourteen surviving frogs were autopsied during the 1st 16 days of June 1976.

Experiment 2. - Sixty-five frogs ( 40 male and 25 female) were collected from the shores of Block Lake, 7 miles W of Parker's Prairie, Otter Tail Co., on 20 October 1979. In this county, 14 tumors $(6.3 \%)$ were observed in 222 frogs collected on four occasions from 1966 to 1971, whereas no tumors were observed in 657 frogs collected on six occasions from 1977 through 1981 (Table 1). Fifteen or fewer frogs were placed in several 10-gal aquaria. The aquaria were elevated at one end so that frogs were permitted to choose a dry or wet environment. They were force-fed a meal of liver and multivitamin-mineral supplement (Clovite) three times weekly. Laboratory temperature was $22 \mathrm{C}( \pm 2)$. Sixty surviving frogs were autopsied on 27 October 1980.

Renal adenocarcinomas were detected at autopsy under a magnifier (3X) with a fluorescent illuminator. Both dorsal and ventral aspects of the mesonephros were examined. A dissecting microscope was used to examine areas of the mesonephros suspected to be tumorous.

\section{Results}

Experiment 1.- Results of maintaining frogs under tumor-promoting laboratory conditions for approximately 8 months are summarized in Table 2. Nine renal adenocarcinomas (18\%) appeared among frogs from the Sand Hill River, and two renal adenocarcinomas (4\%) were obtained from the Chippewa Lake frogs. It is highly plausible that the observed difference in incidence of tumors induced in the Sand Hill River Rana pipiens and the Chippewa Lake $R$. pipiens reflects real differences in vulnerability to tumor induction $\left(2 \times 2\right.$ contingency test, $\left.\mathrm{X}^{2} 1 \mathrm{df}=5.01, \mathrm{p}=0.025\right)$. No tumors were detected in the Diamond Lake or Woodworth frogs.

It is noteworthy that the $18 \%$ incidence of induced tumors in Sand Hill River frogs at the end of Experiment 1 was significantly $(\mathrm{p} \ll 0.005)$ greater than the $3.1 \%$ frequency of spontaneous tumors observed in 96 frogs taken from the same site 3 weeks later than those of Experiment 1 (McKinnell et al., 1979).

Experiment 2. - No tumors were detected in the 60 surviving frogs that were main- 
tained under tumor-promoting conditions for approximately 1 year. These results are also significantly different from those of the Sand Hill area in Experiment 1.

\section{Discussion}

The initial rationale for these experiments was provided by the need to ascertain whether frogs from different geographic locations exhibit differences in vulnerability to tumor induction. There is evidence that Minnesota leopard frogs from the Sand Hill River site were more tumor-prone than frogs from Chippewa Lake and Diamond Lake during the 1975-1976 season.

We also hoped in 1975 to obtain renal tumors for other studies. The method we chose for tumor induction was to maintain wild-caught adults at room temperature for ca. 8 months. Other investigators (reviewed above) and prior experience in this laboratory suggested that we would obtain a tumor frequency between $20-50 \%$. This proved not to be the case.

Because of a continuing demand for renal tumors, we repeated the 1975-1976 experiments in 1979-1980. Several changes were made in experimental protocol. First, we sought an area of Minnesota with a long, proven record of frogs with renal tumors. Otter Tail County has been a source of frogs with spontaneous tumors for a number of years, as shown in Table 1 (cf. McKinnell, 1969; McKinnell and McKinnell, 1968; McKinnell and Zambernard, 1968; Zambernard and McKinnell, 1969; McKinnell and Ellis, 1972a, 1972b). Second, it was considered essential that only large frogs be included in the study, because of the report that larger frogs are more vulnerable than smaller frogs to induction of tumors by maintenance in the laboratory (Rafferty, 1962). Finally, although crowding seems to have no effect in relatively short-term studies (Rafferty, 1963a; Roberts, 1963), there was evidence that crowding enhanced tumor induction in a longer study (DiBerardino and King, 1965). No tumors were detected in the 60 frogs (with an average body length of $85 \mathrm{~mm}$ ) that survived for over 12 months.

The possibility of inducing renal tumors in wild-caught Rana pipiens populations characterized by a reduction or absence of spontaneous tumors in untreated animals provided another rationale for Experiment 2 of this study. The frogs of Experiment 1 were collected at a time (1975) when the decline in spontaneous renal tumors of wildcaught $R$. pipiens was not yet evident. Despite this fact, the frequency of induced tumors was lower than expected. Spontaneous tumors in wild-caught frogs were not seen during 1977-1981 (McKinnell, In press a; McKinnell et al., 1979, 1980) at the Block Lake site in Otter Tail County, or anywhere else in Minnesota. Paralleling this observation, maintenance of the frogs of Experiment 2-caught at Block Lake during 1979 - under tumor-promoting laboratory conditions failed to induce tumors. We believe, therefore, that the low frequency $(0.0 \%)$ of induced tumors at this site in 1979

TABLE 1. - Prevalence of spontaneous renal tumors in wild-caught leopard frogs from Block Lake, Otter Tail County, Minnesota

\begin{tabular}{cccc}
\hline \hline Date of collection & No. of frogs & $\begin{array}{c}\text { Mean snout-vent } \\
\text { length }\end{array}$ & $\begin{array}{c}\text { No. of frogs } \\
\text { with renal tumors }\end{array}$ \\
\hline $4-12-66$ & 100 & 67 & $9(9.0)$ \\
$8-10-67$ & 77 & 72 & $1(1.2)$ \\
$8-18-67$ & 15 & 69 & $1(6.6)$ \\
$5-12-71$ & 30 & 69 & $3(10.0)$ \\
$10-2-77$ & 97 & 68 & $0(0.0)$ \\
$10-20-78$ & 261 & 69 & $0(0.0)$ \\
$10-7-79$ & 91 & 91 & $0(0.0)$ \\
$9-8-80$ & 20 & NM* & $0(0.0)$ \\
$9-26-80$ & 74 & 66 & $0(0.0)$ \\
$4-8-81$ & 114 & 72 & $0(0.0)$ \\
\hline
\end{tabular}

*Not measured 


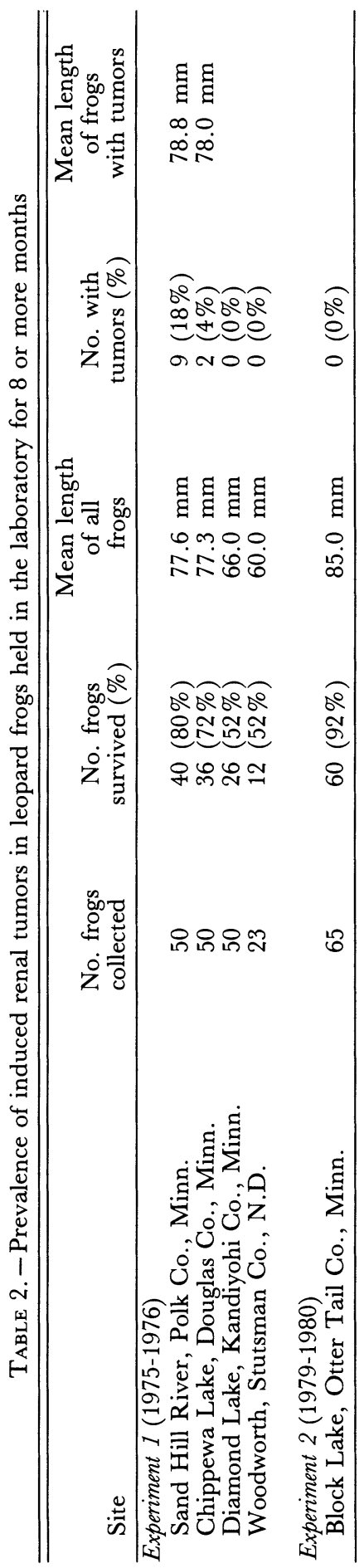


is related to the recent low $(0.0 \%)$ frequency of spontaneous tumors there, which contrasts sharply with the prevalence of $6.3 \%$ in Otter Tail County between 1966 and 1971 (Table 1).

The cause of the present low vulnerability of Rana pipiens at Block Lake to proven tumor-promoting conditions in the laboratory is unknown, but it is postulated that because spontaneous tumors there have declined sharply in frequency in natural populations, it is now difficult for eggs or embryos to be exposed to the Lucké tumor herpesvirus (McKinnell et al., 1979, 1980). The effectiveness of tumor-promoting conditions may be expected to decline as individuals exposed to the oncogenic virus become less frequent in natural populations. If the oncogenic agent is not present in populations of $R$. pipiens, no amount of laboratory stress will produce renal tumors.

Acknowledgments. - This study would not have been possible were it not for the diligent care of the frogs for many months by undergraduate biology students of the University of Minnesota. Stuart Kaufman, Robert Resnick, Maureen Brody and Michael Adkins cared for the frogs of Experiment 1. Jerry Johnson, Ken Ness, Joe Ross and Scott Ward cared for the frogs of Experiment 2. Betsy Kren assisted with data compilation. The study was supported in part by Public Health Service Grant RR-01072 from the Division of Research Resources, National Institutes of Health.

\section{Literature Gited}

Diberardino, M. A. AND T. J. King. 1965. Renal adenocarcinomas promoted by crowded conditions in laboratory frogs. Cancer Res., 25:1910-1912.

Lucké, B. 1934. A neoplastic disease of the kidney of the frog, Rana pipiens. Am. J. Cancer, 20:352-379.

McKinNELl, R. G. 1969. Lucké renal adenocarcinoma: Epidemiological aspects, p. 254-260. In: M. Mizell (ed.). Biology of amphibian tumors. Springer-Verlag, New York. 1973. The Lucké frog kidney tumor and its herpesvirus. Am. Zool., 13:97-114.

The Lucké renal adenocarcinoma: Environmental influences on the biology of the tumor with an appendix concerning chemical mutagenesis. In: C. J. Dawe, J. C. Harshbarger and S. Takayama (eds.). Phyletic approaches to cancer. University Park Press, Baltimore. In press a.

The Lucké tumor: A neoplastic disease of frog kidneys. In: G. L. Hoff, F. L. Frye and E. R. Jacobson (eds.). Diseases of amphibians and reptiles. Iowa State University Press, Ames. In press b.

AND D. P. DUPLANTIER. 1970. Are there renal adenocarcinoma-tree populations of leopard frogs? Cancer Res., 30:2730-2735.

AND V. L. ELLIS. 1972a. Epidemiology of the frog renal tumour and the significance of tumour nuclear transplantation studies to a viral aetiology of the tumour - a review. Int. Agency Res. Cancer Sci. Publ., 2:187-197.

AND . 1972b. Herpesviruses in tumors of postspawning Rana pipiens. Cancer Res., 32:1154-1159.

AND B. K. McKinnelL. 1968. Seasonal fluctuation of frog renal adenocarcinoma prevalence in natural populations. Ibid., 28:440-444.

AND J. ZAMBERNARD. 1968. Virus particles in renal tumors obtained from spring Rana pipiens of known geographic origin. Ibid., 28:684-688.

, E. Gorham, F. B. Martin AND J. W. SchaAd. 1979. Reduced prevalence of the Lucké renal adenocarcinoma in populations of Rana pipiens in Minnesota. J. Natl. Cancer Inst., 63:821-824. carcinoma in Minnesota leopard frogs. Am. Midl. Nat., 104:402-404.

Naegele, R. F., A. Granoff and R. W. Darlington. 1974. The presence of the Lucké herpesvirus genome in induced tadpole tumors and its oncogenicity: Koch-Henle postulates fulfilled. Proc. Natl. Acad. Sci. U.S.A. 71:830-834.

RAFFERTY, K. A. 1962. Age and environmental temperature as factors influencing development of kidney tumors in uninoculated frogs. J. Natl. Cancer Inst., 29:253-265. 1963a. Spontaneous kidney tumors in the frog: Rate of occurrence in isolated adults. Science, 141:720-721. 
1963b. Effect of injected frog-kidney tumor extracts on development of tumors under promoting conditions. J. Natl. Cancer Inst., 30:1103-1113.

AND N. S. RAFFERTY. 1961. High incidence of transmissible kidney tumors in uninoculated frogs maintained in the laboratory. Science, 133:702-703.

Roberts, M. E. 1963. Studies on the transmissibility and cytology of the renal carcinoma of Rana pipiens. Cancer Res., 23:1709-1714.

Zambernard, J. and R. G. McKinnell. 1969. "Virus-free" renal tumors obtained from prehibernating leopard frogs of known geographic origin. Ibid., 29:653-657.

Submitted 24 June 1981

Accepted 14 October 1981 